\title{
Alteration of free sulphydryl content of rat sperm heads by suppression of intratesticular testosterone
}

\author{
H. F. S. Huang and E. Nieschlag \\ Max Planck Clinical Research Unit for Reproductive Medicine, University Women's Hospital, \\ Steinfurter Str. 107, D-4400 Münster, Federal Republic of Germany
}

\begin{abstract}
Summary. Subcutaneous injections of testosterone propionate to adult male rats at a dose of 2.5 or $10 \mathrm{mg} / \mathrm{kg}$ body weight, 3 times per week for 7 weeks, resulted in a $75 \%$ reduction in serum $\mathrm{LH}$ and more than $50 \%$ reduction in intratesticular testosterone concentration, but serum FSH levels remained unchanged. The free -SH content, measured as iodo $\left[{ }^{14} \mathrm{C}\right]$ acetamide binding, increased by $70-100 \%$ in testicular sperm heads after suppression of testicular testosterone, and by $25-30 \%$ in caput epididymal sperm heads but was decreased by $70-80 \%$ in cauda epididymal sperm heads. These results demonstrate an alteration in the oxidative state of sperm nuclear basic proteins, suggesting incomplete nuclear maturation. These changes may be specific for the suppression of intratesticular testosterone, thus illustrating the androgen dependency of sperm head maturation. The contrast effects noted between the iodo[ $\left.{ }^{14} \mathrm{C}\right]$ iodoacetamide binding by the caput and the cauda epididymal sperm heads indicate that testosterone propionate treatment may affect the mechanisms regulating the oxidation of the sulphydryl residues in sperm heads during epididymal transit. This alteration may not directly relate to the tissue androgen concentrations.
\end{abstract}

\section{Introduction}

During the final stages of mammalian spermatogenesis, spermatids undergo a series of morphological changes which include the expulsion of cytoplasm, condensation of cell nuclei and development of the species-specific sperm head morphology (Clermont, 1972). Concomitantly, the lysine-rich, somatic histones are replaced by arginine-rich sperm basic proteins which contain cysteine predominating at specific stages of spermiogenesis (Monesi, 1965; Vaughn, 1966; Gledhill, Gledhill, Rigler \& Ringertz, 1966; Kopecny, 1970; Meistrich, Reid \& Barcellona, 1976). The replacement of histones by the basic proteins and perhaps, to some extent, the formation of disulphide cross-linkage between basic protein molecules are thought to be responsible for the condensation of the sperm nucleus during the final stages of spermatogenesis (Marushige \& Marushige, 1974; Meistrich et al., 1976; Grimes, Meistrich, Platz \& Hnilica, 1977).

Sperm heads become further stabilized during their transit through the epididymis (Calvin \& Bedford, 1971). The binding of iodo- $\left[{ }^{14} \mathrm{C}\right]$ acetamide, an alkylating agent used for the measurement of the -SH content, decreases as sperm travel from the caput to cauda epididymidis (Calvin, Yu \& Bedford, 1973). The stabilization of sperm heads during epididymal transit is considered a part of sperm maturation and may be important for fertility (Bedford, Bent \& Calvin, 1973a).

Androgens are considered essential for the final stages of spermatogenesis (Steinberger, 1971; Vernon, Go \& Fritz, 1975), as well as for epididymal function and sperm maturation (OrgebinCrist, 1969; Bedford, 1975). However, the link between the androgen requirement and the 
condensation of sperm nuclei has not been demonstrated. The present study was therefore designed to investigate the effect of the suppression of intratesticular testosterone concentration on sperm nuclei at different stages of maturation by examining the free sulphydryl content in sperm heads.

\section{Materials and Methods}

Animals

Mature male Sprague-Dawley rats (300-350 g) were assigned to one of the three treatment groups to receive 3 times per week (Monday, Wednesday and Friday) for 7 weeks a subcutaneous injection of (1) 0, (2) 2.5 or (3) $10 \mathrm{mg}$ testosterone propionate (Sigma, St Louis, MO, U.S.A.) per kg body weight in $0.1 \mathrm{ml}$ sesame oil. All rats were caged individually in an air-conditioned, lightcontrolled animal room and were provided with standard rat pellets and water ad libitum.

\section{Blood sampling}

On the Monday of the 8th week, blood samples were taken from the retro-orbital sinus of each rat under light ether anaesthesia immediately before, and then 2 and $24 \mathrm{~h}$ after the last testosterone propionate injection. Animals were then killed by an overdose of ether.

\section{Serum hormone measurement}

Gonadotrophins. Serum FSH and LH were measured by radioimmunoassays using reagents provided by NIAMDD, Rat Pituitary Distribution programme. Rat-FSH-RP1, Rat-FSH-I4, antirat-FSH-S10 and rat-LH-RP1, rat-LH-I4 and anti-rat-LH-S5 were used for the FSH and LH assays respectively. The conditions of these assays have been reported previously (Huang \& Hembree, 1979). The sensitivities of the assays were $50 \mathrm{ng} \mathrm{FSH} / \mathrm{ml}$ serum and $2 \mathrm{ng} \mathrm{LH} / \mathrm{ml}$ serum. The intraassay coefficient of variation was $8.2 \%$ for FSH and $8.7 \%$ for $\mathbf{L H}$. To avoid interassay variation, FSH or LH were measured in one assay for all samples.

Testosterone. Since serum DHT concentration in the male rat is $5 \%$ of the serum testosterone values (Frankel, Mock, Wright \& Kamel, 1975) and measurement of testosterone in dilutions of unchromatographed serum extract yielded as good parallelism to the standard curve as did the chromatographed extracts (H. F. S. Huang, I. Dyrenfurth, G. Gunsalus \& W. C. Hembree, unpublished observation), testosterone was measured in serum extracts by radioimmunoassay according to the method of Nieschlag \& Loriaux (1972) without chromatography. The sensitivity of the assay is $15 \mathrm{pg} / \mathrm{ml}$ serum and the intra- and inter-assay coefficients of variation were $3.7 \%$ and $11.9 \%$, respectively.

\section{Testicular testosterone determination}

Testicular tissues (80-120 mg) were homogenized in $1 \mathrm{ml} \mathrm{0.9 \%} \mathrm{NaCl}$ and extracted 3 times with $5 \mathrm{ml}$ ether. Testosterone was separated from other steroids by thin-layer chromatography and then measured by radioimmunoassay (Nieschlag \& Loriaux, 1972). An aliquant equivalent to $10-20 \%$ of the chromatographed testosterone fraction capable of replacing 30-70\% of radioactive tracer was used in the assay. The recovery of $\left[{ }^{3} \mathrm{H}\right]$ testosterone after extraction and chromatography ranged between 70 and $80 \%$. The coefficient of variation within the assay was $9.8 \%$.

\section{Epididymal androgen determination}

Epididymal tissues (100-150 $\mathrm{mg}$ ) were homogenized in $2 \mathrm{ml} 0.9 \% \mathrm{NaCl}$. After the addition of 1000 c.p.m. $\left[{ }^{3} \mathrm{H}\right]$ testosterone and 1000 c.p.m. $\left[{ }^{3} \mathrm{H}\right]$ dihydrotestosterone $(\mathrm{DHT})$ the homogenates 
were extracted twice with $10 \mathrm{ml}$ ether. Because of the high lipid content in the epididymal tissue, extra steps were used to remove the fat from the extract (Vreeburg, 1975). Briefly, after the ether extracts from each tissue were combined and dried, the residues were dissolved in $5 \mathrm{ml}$ of an acetone-water mixture $(70: 30, \mathrm{v}: \mathrm{v})$ and allowed to stand in a $-30^{\circ} \mathrm{C}$ methanol bath for $30 \mathrm{~min}$. The acetone-water fractions were removed and dried under a stream of air overnight. The residues were then dissolved in $1 \mathrm{ml} n$-heptane :chloroform mixture $(8: 1, \mathrm{v}: \mathrm{v})$. The solution was removed and dried. The residues were dissolved in $100 \mu \mathrm{l}$ methanol and then subjected to thin-layer chromatography and radioimmunoassay for testosterone and DHT according to the method of Nieschlag \& Loriaux (1972). An aliquot equivalent to $20 \%$ or $5 \%$ of the chromatographed testosterone or DHT fraction, respectively, capable of replacing 30-70\% of radioactive tracer, was used in the radioimmunoassay. The recovery of the radioactive tracer after extraction and chromatography was $70-80 \%$ and $40-60 \%$ for testosterone and DHT, respectively. The intra-assay coefficient of variation was $13.9 \%$ for testosterone and $12.7 \%$ for DHT.

\section{Measurement of free $-\mathrm{SH}$ content}

The free $-\mathrm{SH}$ residues of sperm heads were measured by the binding of iodo $\left[{ }^{14} \mathrm{C}\right]$ acetamide according to the following procedure. The testes and the epididymides of each rat were dissected and kept in ice-cold buffer containing $0.025 \mathrm{M}$-sodium phosphate, $10 \mathrm{~mm}$-Tris- $\mathrm{HCl}$ and $0.1 \mathrm{~mm}$ EDTA (pH 7.0) until all rats had been killed. Two thirds of one testis and the caput or cauda epididymidis (separated at the middle point of the corpus) were each homogenized in $10 \mathrm{ml}$ of the same buffer at $2-4^{\circ} \mathrm{C}$. The homogenates were filtered through 3 layers of cheese cloth. The filtrates were centrifuged at $3500 \mathrm{~g}$ for $15 \mathrm{~min}$ at $4^{\circ} \mathrm{C}$. The pellets were resuspended in $1 \mathrm{ml}$ (testicular cells) or $0.5 \mathrm{ml}$ (epididymal cells) of the same buffer and dispersed by brief sonication. A $400 \mu$ l aliquant of the cell suspension was incubated with $0.1 \mathrm{ml}$ iodo $\left[{ }^{14} \mathrm{C}\right]$ acetamide $(100 \mathrm{nmol}$; sp. act. 838000 d.p.m./nmol) in a $25^{\circ} \mathrm{C}$ water bath for $60 \mathrm{~min}$. These conditions were chosen after a series of preliminary experiments. At the end of the incubation, the reaction was stopped by adding $0.1 \mathrm{ml}$ of $1 \mathrm{~mm}$ non-radioactive iodoacetamide then $3 \mathrm{ml}$ ice-cold distilled water. After the samples had been centrifuged at $3500 \mathrm{~g}$ for $15 \mathrm{~min}$, the pellets were washed 3 times with ice-cold distilled water. The final pellets were stored at $-30^{\circ} \mathrm{C}$.

Sperm heads were isolated by discontinuous sucrose gradient sedimentation centrifugation after sonication (Calvin, 1976a). The sperm heads were then washed with phosphate buffer. The iodo $\left[{ }^{14} \mathrm{C}\right]$ acetamide bound to sperm heads was determined by counting the radioactivity of $0 \cdot 1 \mathrm{ml}$ sperm head suspension in $4 \mathrm{ml}$ scintillation counting solution (Aqualuma, Lumac B.V., The Netherlands). The data are expressed as pmol $/ 10^{6}$ sperm heads.

\section{Morphological response of sperm heads to SDS-DTT treatment}

An aliquant of $50 \mu \mathrm{l}$ sperm head suspension was incubated with $500 \mu 11 \%$ SDS in $0.05 \mathrm{M}$-sodium borate (pH 9.0) in the presence or absence of 0.002 M-DTT for 15-60 min (Calvin \& Bedford, 1971). At the end of incubation $5 \mathrm{ml}$ distilled water were added and the tubes were centrifuged at $330 \mathrm{~g}$ for $10 \mathrm{~min}$. The pellets were dispersed by gentle pipetting and the extent of sperm head swelling was examined by phase contrast microscopy.

\section{Statistics}

Student's $t$ test was used to compare the mean values between control and testosterone propionate-treated rats. 


\section{Results}

Organ weights

In mature male rats 3 injections per week of 2.5 or $10 \mathrm{mg}$ testosterone propionate per $\mathrm{kg}$ body weight for 7 weeks resulted in a significant reduction of testicular weights $(P<0.001)$, but epididymal weights were not affected (Table 1).

Table 1. Organ weights and serum hormonal concentration of rats after testosterone propionate treatment

\begin{tabular}{|c|c|c|c|}
\hline & \multicolumn{3}{|c|}{ Dose of testosterone propionate ( $\mathrm{mg} / \mathrm{kg}$ body wt) } \\
\hline & $\begin{array}{c}0 \\
\text { (control) }\end{array}$ & $2 \cdot 5$ & 10 \\
\hline No. of rats & 6 & 5 & 5 \\
\hline $\begin{array}{r}\text { Testicular } \\
\text { wt (mg) }\end{array}$ & $1916 \pm 30$ & $1206 \pm 11^{* * *}$ & $1501 \pm 13^{*}$ \\
\hline $\begin{array}{c}\text { Epididymal } \\
\text { wt (mg) }\end{array}$ & $629 \pm 17$ & $561 \pm 42$ & $663 \pm 41$ \\
\hline \multicolumn{4}{|c|}{ Serum hormone conc. (ng/ml) } \\
\hline $\mathbf{0 ~ h}$ & $2.2 \pm 0.6$ & $2.8 \pm 0.5$ & $3.85 \pm 1 \cdot 5$ \\
\hline $2 \mathrm{~h}$ & $1 \cdot 1 \pm 0 \cdot 1$ & $12.6 \pm 1.4^{* * *}$ & $27 \cdot 18 \pm 2 \cdot 0^{* * *}$ \\
\hline $24 \mathrm{~h}$ & $1 \cdot 1 \pm 0 \cdot 1$ & $3.9 \pm 0.6$ & $11 \cdot 18 \pm 3 \cdot 1^{* *}$ \\
\hline FSH & $189 \pm 8$ & $196 \pm 25$ & $180 \pm 44$ \\
\hline LH & $17 \pm 5$ & $3 \pm 1 * * *$ & $3 \pm 1^{* * *}$ \\
\hline \multicolumn{4}{|c|}{ Epididymal androgen conc. $(\overline{\mathrm{pg}} / \mathrm{mg})$} \\
\hline Testosterone & $14 \cdot 2 \pm 3 \cdot 4$ & $15 \cdot 7 \pm 4 \cdot 1$ & $14.2 \pm 3.8$ \\
\hline $\mathrm{DHT}$ & $22.5 \pm 2.4$ & $29.5 \pm 4.4$ & $28.6 \pm 3.0$ \\
\hline \multicolumn{4}{|l|}{ Cauda } \\
\hline Testosterone & $5 \cdot 5 \pm 1 \cdot 1$ & $3.9 \pm 0.9$ & $5.8 \pm 1.4$ \\
\hline DHT & $12.0 \pm 1.8$ & $11.7 \pm 2.3$ & $12 \cdot 2 \pm 2 \cdot 0$ \\
\hline
\end{tabular}

Values are mean \pm s.e.m.

Compared to control group values, ${ }^{*} P<0.01,{ }^{* *} P<0.05,{ }^{* *} P<$ $0 \cdot 001$.

\section{Serum hormone concentrations}

Serum testosterone levels were comparable in the 3 groups before the last injection was given (Table 1). It increased by 10- or 25-fold, respectively, above that of the control values $2 \mathrm{~h}$ after the injection of 2.5 or $10 \mathrm{mg}$ testosterone propionate per $\mathrm{kg}$ body weight $(P<0.001)$. The testosterone levels declined by $60-75 \% 24 \mathrm{~h}$ after the injection but remained significantly elevated compared to the control rat values $(P<0.05)$. By $24 \mathrm{~h}$ after the last testosterone injection serum $\mathrm{LH}$ levels were $75 \%$ lower than those of the controls $(P<0.001$; Table 1), but serum FSH levels were not affected (Table 1).

\section{Intratesticular testosterone concentration}

The mean \pm s.e.m. intratesticular testosterone concentrations were $36 \pm 4,17 \pm 3$ and $12 \pm$ $0.8 \mathrm{pg} / \mathrm{mg}$ tissue in the rats treated with $0,2.5$ or $10 \mathrm{mg}$ testosterone propionate, respectively. The effect of testosterone propionate was significant $(P<0.01)$ for both doses and the degree of reduction appeared to be dose-dependent. 


\section{Epididymal androgen concentrations}

The epididymal androgen concentrations are presented in Table 1. Testosterone and DHT levels in the caput and cauda epididymidis were not affected by the testosterone propionate treatments although the DHT levels in the caput epididymidis tended to be increased.

\section{Iodo $\left[{ }^{14}\right.$ Clacetamide binding by sperm heads}

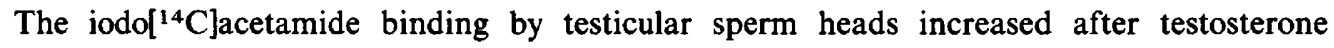
propionate treatment (Text-fig. 1). Sperm heads from the caput epididymidis of testosterone propionate-treated rats also bound more iodo $\left[{ }^{14} \mathrm{C}\right]$ acetamide than did the control rats but sperm heads from the cauda epididymidis showed decreased binding of iodo $\left[{ }^{14} \mathrm{C}\right]$ acetamide after testosterone propionate treatment (Text-fig. 1).

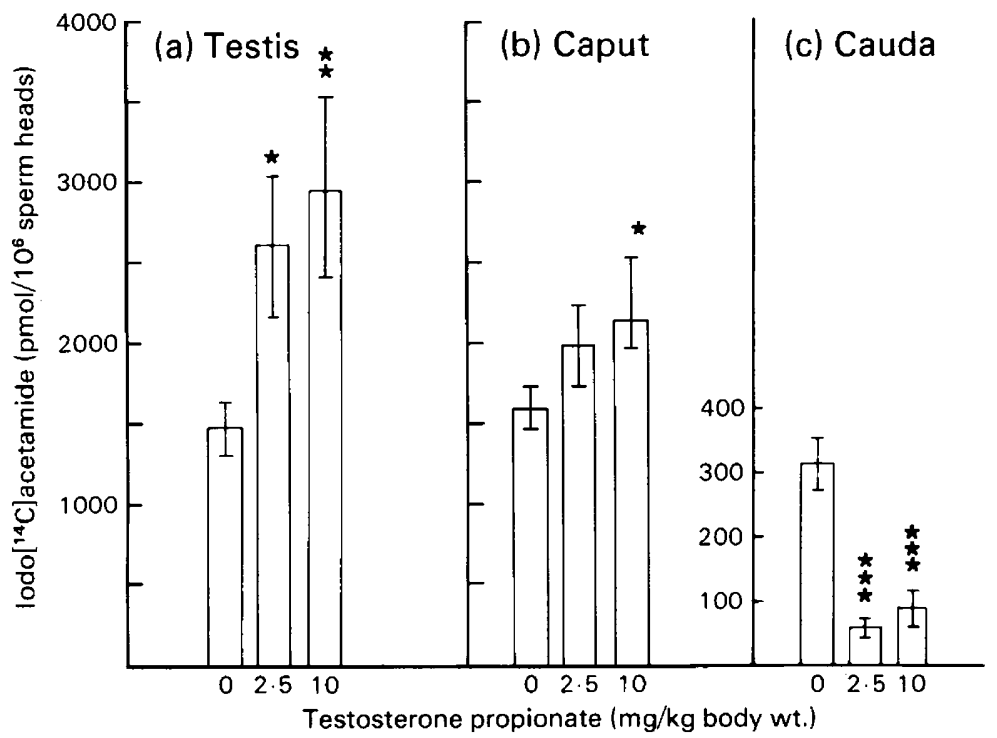

Text-fig. 1. Binding of iodo $\left[{ }^{14} \mathrm{C}\right]$ acetamide by sperm heads isolated from (a) testis, (b) caput epididymidis and (c) cauda epididymidis after testosterone propionate treatment. Values are mean \pm s.e.m. for 5 or 6 rats (see Table 1 ). ${ }^{*} P<0.05 ;{ }^{* *} P<0.025 ;{ }^{* *} P<0.001$ compared with value for control group $(0 \mathrm{mg})$.

\section{Sperm head response to SDS-DTT treatment}

The sperm heads isolated by the procedures described are shown in Pl. 1, Figs 1-4. No difference was noted between samples from testosterone propionate-treated animals and those of control animals. After exposure to SDS with or without DTT, the degree of sperm head swelling was comparable between experimental and control rats (Pl. 2, Figs $5 \& 6$ ).

\section{Discussion}

The present study demonstrates that in mature male rats chronic treatment with testosterone propionate resulted in alteration of the iodo $\left[{ }^{14} \mathrm{C}\right]$ acetamide binding of sperm heads at different stages of maturation. This result illustrates a change in the character of sperm heads. Cunningham \& Huckins (1979) found that daily injections of $25 \mu \mathrm{g}-1 \mathrm{mg}$ testosterone propionate per $\mathrm{kg}$ body 
weight suppressed testicular testosterone concentrations by $50-90 \%$. In addition, both LH and FSH were suppressed significantly at the dose of $1 \mathrm{mg} / \mathrm{kg}$ body weight (Cunningham \& Huckins, 1979). In the present study, injection of 2.5 or $10 \mathrm{mg}$ testosterone propionate per kg body weight 3 times per week resulted in $75 \%$ reduction in serum LH levels. This decrease in LH was apparently responsible for the $>50 \%$ reduction in intratesticular testosterone concentration in these rats. In contrast, serum FSH levels were normal at the time when animals were killed. The different serum LH and FSH responses observed in the present study, and the different FSH response between this study and the study of Cunningham \& Huckins (1979) may be attributable to the alteration of GnRH pulsing by the fluctuating serum testosterone levels (Steiner, Bremner \& Clifton, 1982) thereby modifying the pituitary sensitivity to the steroid negative feedback (Lincoln, 1979; Wildt $e t$ al., 1981).

The increased iodo $\left[{ }^{14} \mathrm{C}\right]$ acetamide binding by testicular sperm heads indicates an increase in the free -SH content. Although sulphydryl residues associated with other membrane structures (Bedford, Calvin \& Cooper, 1973b) may also react with iodo $\left[{ }^{14} \mathrm{C}\right]$ acetamide during incubation, the procedure used to purify sperm heads (extensive sonication in distilled water) was probably sufficient to remove most, if not all, the -SH containing structures except the chromatin-bound basic proteins and, perhaps, the perforatorium. The change in -SH content may therefore reflect a modification in the sperm nucleus. Since the disulphide cross-linkage in testicular sperm heads is negligible (Marushige \& Marushige, 1974), the higher free -SH content measured in the testicular sperm heads after testosterone propionate treatment cannot be explained by an insufficient disulphide cross-linkage. Furthermore, the normal sperm head morphology before and after SDSDTT treatment suggests that the total -SH content or the component of the basic proteins in sperm heads probably was not affected by testosterone propionate treatment. Therefore, the higher -SH contents may result from an increase in the proportion of sperm heads containing S1 protein, which has 3 times more cysteine residue than other basic proteins (Kistler, Geroch \& Williams-Ashman, 1973; Calvin, 1976b; Grimes et al., 1977), due to a delay in the transport of spermatozoa from the testis to the epididymis or to the destruction of younger elongated spermatids (containing basic proteins with less cysteine residues) during the preparation of sperm heads. It is also possible that suppression of testicular testosterone concentration results in a modification in the folding of chromatin or the configuration of sperm nuclei, making the -SH residue more available to react with iodoacetamide. Although serum FSH may be suppressed temporarily after each testosterone propionate injection, the normal serum FSH at the time when the animals were killed suggests that the testes of the treated rats probably had been exposed to relatively normal serum FSH levels during the experimental period. Therefore, the change in the sperm head character may represent a specific effect of the reduction of intratesticular testosterone. This is compatible with the concept that androgen is required for the final stages of spermatogenesis (Steinberger, 1971; Vernon et al., 1975).

Stabilization of sperm nuclei during epididymal transit is thought to be regulated by the epididymal environment (Bedford et al., 1973a), which is androgen-dependent (Orgebin-Crist, 1969; Bedford, 1975). In the present study caput epididymal androgen concentrations remained unchanged after testosterone propionate treatments. Yet the binding of iodo $\left[{ }^{14} \mathrm{C}\right]$ acetamide by sperm heads recovered from this region had also increased. Since the caput epididymidis receives

\section{PLATE 1}

Photomicrographs of rat sperm heads. $\times 160$.

Fig. 1. Testicular sperm heads from control animals.

Fig. 2. Testicular sperm heads from rats receiving $10 \mathrm{mg}$ testosterone propionate.

Fig. 3. Caput epididymal sperm heads from control rats.

Fig. 4. Caput epididymal sperm heads from rats receiving $10 \mathrm{mg}$ testosterone propionate. 
PLATE 1
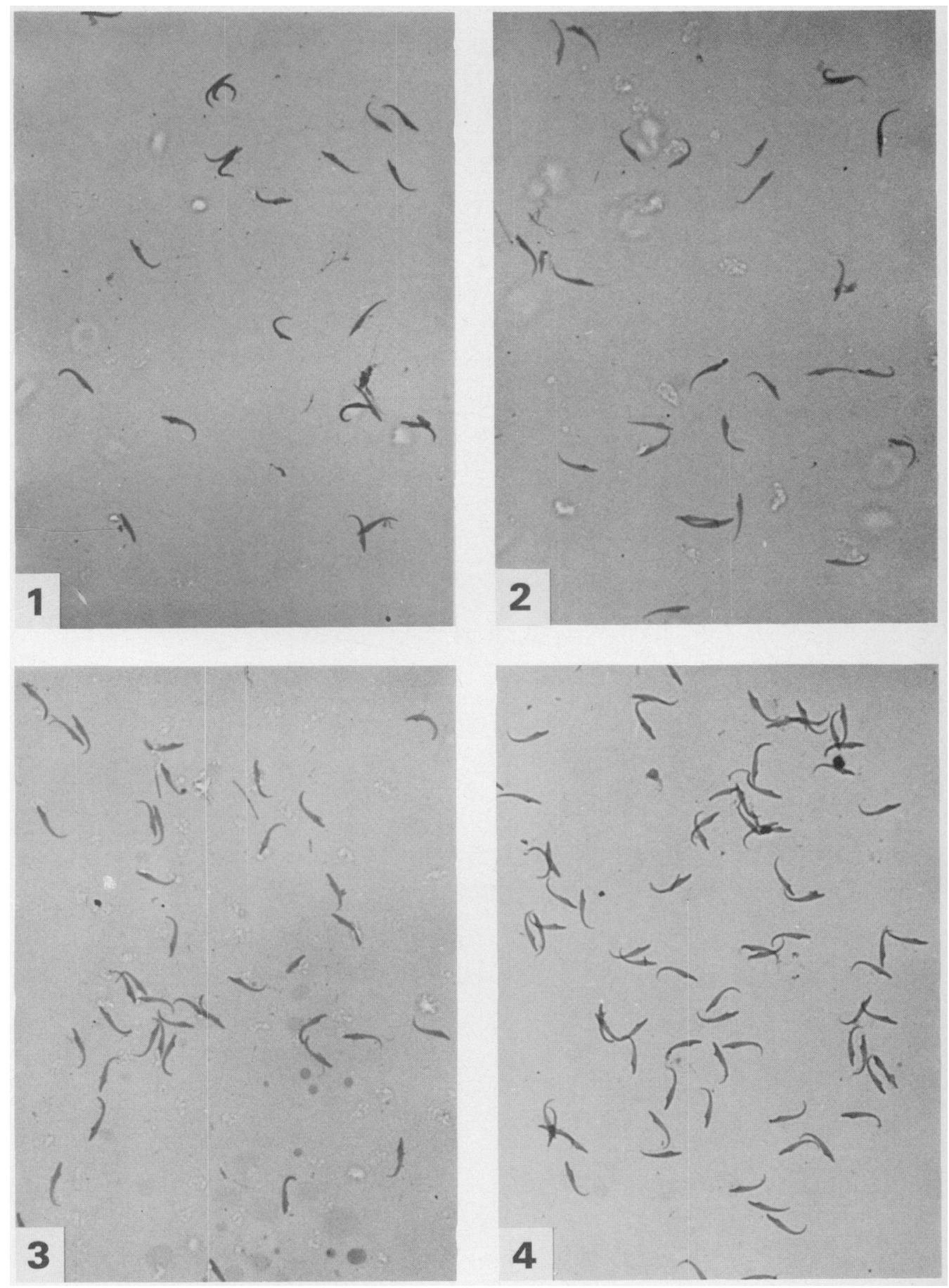

(Facing p. 36) 
PLATE 2
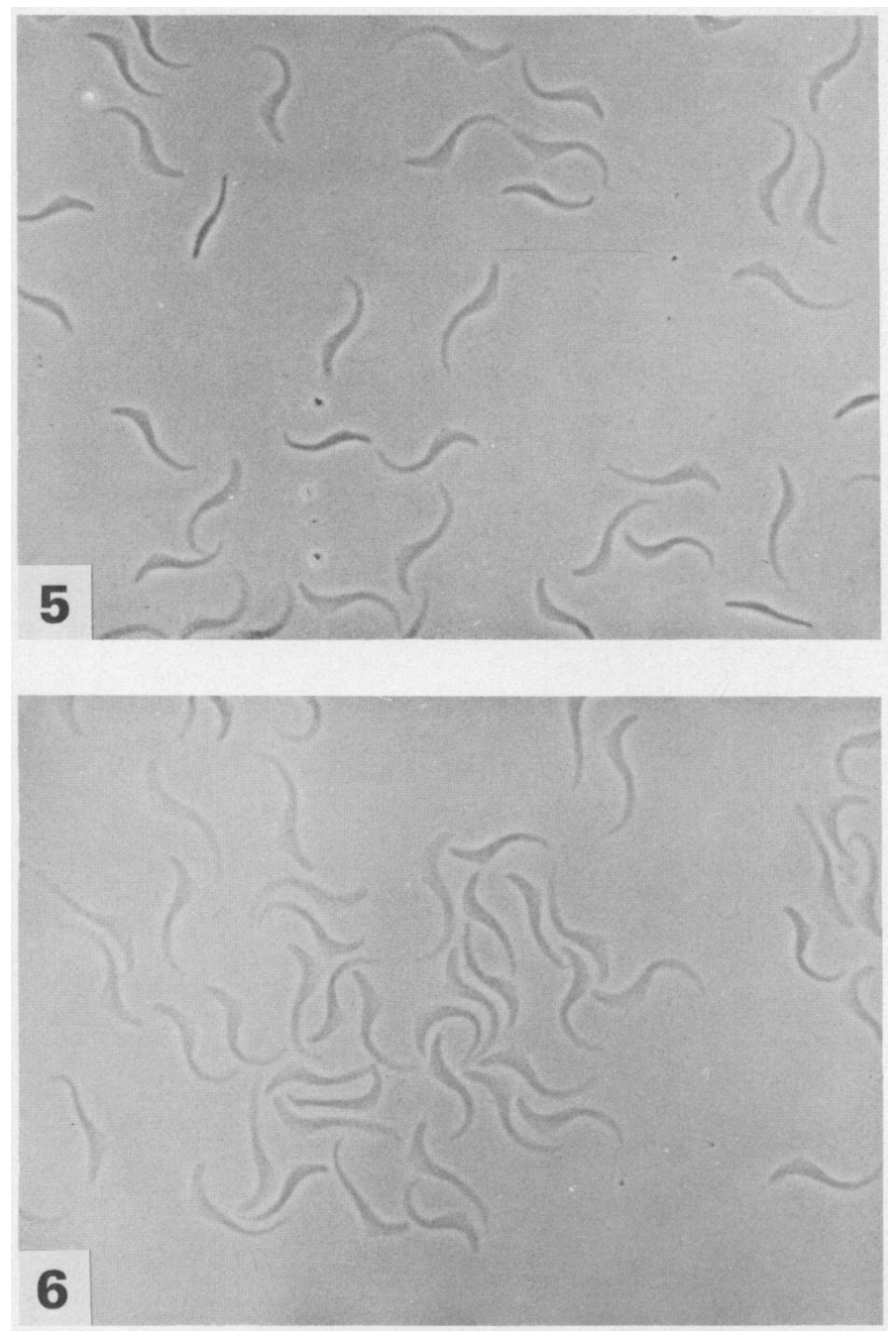

Photomicrographs of rat sperm heads after exposure to SDS-DTT for $60 \mathrm{~min}$, showing similar degrees of swelling of sperm heads from the cauda epididymidis of control rats (Fig. 5) and rats treated with $10 \mathrm{mg}$ testosterone propionate (Fig. 6). 
newly released testicular spermatozoa bathed in rete testis fluid, it is not surprising that spermatozoa recovered from this region share the same character with those recovered from the testis. On the other hand, the reduction in iodo $\left[{ }^{14} \mathrm{C}\right]$ acetamide binding by sperm heads from the cauda epididymidis after testosterone propionate treatment may reflect an enhanced disulphide cross-linkage formation. Since the treatment period ( 7 weeks) was 3-4 times longer than that required for spermatozoa to travel from the testis to the cauda epididymidis (10-14 days; Hamilton, 1972), the sperm heads recovered from different regions of the epididymis should have been exposed to a common intratesticular environment during their spermiogenic development. Thus, the difference in the iodo $\left[{ }^{14} \mathrm{C}\right]$ acetamide binding by sperm heads at various phases of maturation probably is not related to the change in the total -SH content of sperm heads. It is more likely to be related to the alteration in the oxidative states of $-\mathrm{SH}$ residues of sperm heads. Since spermatozoa are transported in fluid originated from the rete testis or secretions from epididymal cells, the differences observed in the sperm heads from different regions of the epididymis may relate to an abnormal tubular milieu which is not directly related to the epididymal tissue androgen concentration.

Condensation of sperm nuclei requires phosphorylation and dephosphorylation of the sperm basic proteins (Marushige \& Marushige, 1975). These modifications of the basic proteins may be important for the formation of disulphide cross-linkages during epididymal maturation (Marushige \& Marushige, 1975). On the other hand, the presence of glutathione in rat testis (Calvin \& Turner, 1982) and in the spermatozoa and seminal plasma of other species ( $\mathrm{Li}, 1975$; Smith, Senger, McCutchan \& Landa, 1979) suggests a possible role for glutathione in the protection of sperm cells against oxidation which, in turn, may influence the oxidative state of the basic proteins (Mann \& Lutwak-Mann, 1981; Calvin \& Turner, 1982). A decrease in intratesticular testosterone concentration and a change in epididymal physiology under the influence of the fluctuating circulatory testosterone concentrations may alter the enzyme systems responsible for the regulation of sulphydryl oxidation at various phases of sperm maturation, thus resulting in a change in free -SH content.

We thank Ms A. Guderjahn and A. Over for their technical assistance; Dr M. Rea for critical review of the manuscript; and Dr A. F. Parlow and the NIH Rat Pituitary Hormone Distribution Program, U.S.A., for the FSH and LH assay kits.

\section{References}

Bedford, J.M. (1975) Maturation, transport and the fate of spermatozoa in the epididymis. In Handbook of Physiology, Section 7, Endocrinology, Vol. V: Male Reproductive System, pp. 303-318. Eds D. W. Hamilton \& R. O. Greep. Am. Physiol. Soc., Washington, D.C.

Bedford, J.M., Bent, M.J. \& Calvin H.I. (1973a) Variations in the structural character and stability of the nuclear chromatin in morphologically normal human spermatozoa. J. Reprod. Fert. 33, 19-29.

Bedford, J.M., Calvin, H. \& Cooper, G.W. (1973b) The maturation of spermatozoa in the human epididymis. J. Reprod. Fert., Suppl. 18, 199-213.

Calvin, H.I. (1976a) Isolation and subfractionation of mammalian sperm heads and tails. Methods Cell. Biol. 13, 85-104.

Calvin, H.I. (1976b) Comparative analysis of the nuclear basic proteins in rat, human, guinea pig, mouse and rabbit spermatozoa. Biochim. Biophys. Acta 434, 377389.
Calvin, H.I. \& Bedford, J.M. (1971) Formation of disulphide bonds in the nucleus and accessory structures of mammalian spermatozoa during maturation in the epididymis. J. Reprod. Fert., Suppl. 13, $65-75$.

Calvin, H.I. \& Turner, S.I. (1982) Postnatal increases in rat testis glutathione: correlation with changes in germ cell composition. In The Cell Biology of the Testis, pp. 430-432. Eds C. W. Bardin \& R. J. Sherins. N.Y. Acad. Sci. New York.

Calvin, H.I., Yu, C.C. \& Bedford, J.M. (1973) Effects of epididymal maturation, zinc (II) and copper (II) on the reactive sulfhydryl content of structural elements in rat spermatozoa. Expl Cell Res. 81, 333341 .

Clermont, Y. (1972) Kinetics of spermatogenesis in mammals: seminiferous epithelium cycle and spermatogonial renewal. Physiol. Review 52, 198-236.

Cunningham, G.R. \& Huckins, C. (1979) Persistence of complete spermatogenesis in the presence of low 
intratesticular concentration of testosterone. Endocrinology 105, 177-186.

Frankel, A.I., Mock, E.J., Wright, W.W. \& Kamel, F. (1975) Characterization and physiological validation of a radioimmunoassay for plasma testosterone in the male rat. Steroids 25, 73-98.

Gledhill, B.L., Gledhill, M.P., Rigler, R., Jr \& Ringertz, N.R. (1966) Changes in deoxyribonucleoprotein during spermiogenesis in the bull. Expl Cell Res. 41, $652-665$.

Grimes, S.R., Meistrich, M.L., Platz, R.D. \& Hnilica, L.S. (1977) Nuclear protein transitions in rat testis spermatids. Expl Cell Res. 110, 31-39.

Hamilton, D.W. (1972) The mammalian epididymis. In Reproductive Biology, pp. 268-337. Eds H. Balin \& S. Glaser. Excerpta Medica, Amsterdam.

Huang, H.F.S. \& Hembree, W.C. (1979) Spermatogenic response to vitamin $A$ in vitamin $A$ deficient rat. Biol. Reprod. 21, 891-904.

Kistler, W.S., Geroch, M.E. \& Williams-Ashman, H.G. (1973) Specific basic proteins from mammalian testis. J. biol. Chem. 248, 4532-4543.

Kopecny, V. (1970) Labelling of mouse spermatozoa with L-arginine ${ }^{14} \mathrm{C}(\mathrm{u})$ monohydrochloride. $Z$. Zellforsch. mikrosk. Anat. 109, 414-419.

Li, T.K. (1975) The glutathione and thiol content of mammalian spermatozoa and seminal plasma. Biol. Reprod. 12, 641-646.

Lincoln, G.A. (1979) Differential control of luteinizing hormone and follicle stimulating hormone by luteinizing hormone releasing hormone in the ram. $J$. Endocr. 80, 133-140.

Mann, T. \& Lutwak-Mann, C. (1981) Biochemistry of spermatozoa: chemical and functional correlations in ejaculated semen, andrological aspects. 2. Sperm plasma membrane: permeability and binding properties. In Male Reproductive Function and Semen, pp. 217-225. Springer Verlag, Berlin.

Marushige, Y. \& Marushige, K. (1974) Properties of chromatin isolated from bull spermatozoa. Biochim. Biophys. Acta 340, 498-508.

Marushige, Y. \& Marushige, K. (1975) Transformation of sperm histone during formation and maturation of rat spermatozoa. J. biol. Chem. 250, 39-45.

Meistrich, M.L., Reid, B.O. \& Barcellona, W.I. (1976) Changes in sperm nuclei during spermiogenesis and epididymal maturation. Expl Cell Res. 99, 72-78.

Monesi, V. (1965) Synthetic activities during spermatogenesis in the mouse: RNA and protein. Expl Cell Res. 39, 197-224.

Nieschlag, E. \& Loriaux, D.L. (1972) Radioimmunoassay for plasma testosterone. Z. Klin. Chem. Biochem. 10, 164-168.

Orgebin-Crist, M.C. (1969) Studies on the function of the epididymis. Biol. Reprod., Suppl. 1, 155-175.

Smith, D.M., Senger, P.L., McCutchan, J.F. \& Landa, C.A. (1979) Selenium and glutathione peroxidase distribution in bovine semen and selenium-75 retention by the tissue of the reproductive tract in the bull. Biol. Reprod. 20, 377-383.

Steinberger, E. (1971) Hormonal control of mammalian spermatogenesis. Physiol. Rev. 51, 1-22.

Steiner, R.A., Bremner, W.J. \& Clifton, D.K. (1982) Regulation of luteinizing hormone pulse frequency and amplitude by testosterone in the adult male rat. Endocrinology 111, 2055-2061.

Vaughn, J. (1966) The relationship of the sphere chromatophile to the fate of displaced histones following histone transition in rat spermiogenesis. $J$. Cell Biol. 31, 257-278.

Vernon, R.G., Go, V.L.W. \& Fritz, I.B. (1975) Hormonal requirement of the different cycles of the seminiferous epithelium during reinitiation of spermatogenesis in long-term hypophysectomized rats. $J$. Reprod. Fert. 42, 77-94.

Vreeburg, J.T.M. (1975) Distribution of testosterone and $5 \alpha$-dihydrotestosterone in rat epididymis and their concentrations in efferent duct fluid. J. Endocr. 67, 203-210.

Wildt, L., Hausler, A., Marshall, G., Hutchinson, J.S., Plant, T.M., Belchetz, P.E. \& Knobil, E. (1981) Frequency and amplitude of gonadotropin releasing hormone stimulation and gonadotropin secretion in the rhesus monkey. Endocrinology 109, 376-385.

Received 17 March 1983 